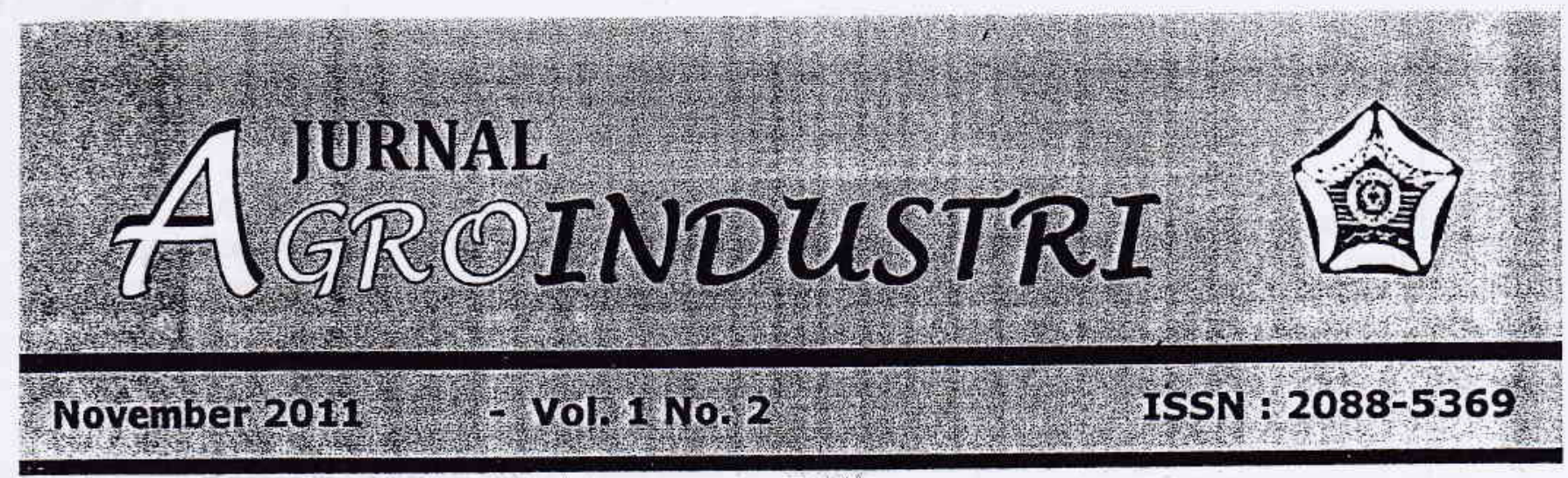

ANALISIS PENURUNAN KUALITAS MINYAK GORENG CURAH SELAMA PENGGORENGAN KERUPUK JALIN

Wuri Marsigit, Budiyanto dan Mukhsin

PERSEPSI MASYARAKAT TERHADAP PENGGUNAAN BRIKET CANGKANG KELAPA SAWIT SEBAGAI BAHAN BAKAR ALTERNATIF PENGGANTI MINYAK TANAH

Hasan Basri Daulay, Lukman Hidayat dan Agung Sudrajad

APIIKASI STARTER KULTUR MURNI PADA PEMBUATAN DURIAN FERMENTASI

Hasanuddin

KAJIAN PEGGUNAAN BERBAGAI JENIS BIOBRIKET SEBAGAI ALTERNATIF PENGGANTI MINYAK TANAH UNTUK RUMAH TANGGA

Budiyanto, Pandu Imam dan Sari Puspita Ningsih

PENDUGAAN UMUR SIMPAN DAN TINGKAT PENERIMAAN KONSUMEN PADA PEMBUATAN PRODUK BIOFARMAKA BERBASIS TERIPANG PASIR (Holothuria scabra) SEBAGAI ANTI FUNGI

Kumia Harlina Dewi, Laili Susanti, Devi Silsia, Irawanto

PENGARUH EKSTRAKSI DAN JENIS BAHAN PENGIKAT TERHADAP PERMEN TABLET BUAH MENGKUDU (Morinda citrifolia)

Lina Widawati

PENGARUH LUMPUR SAWIT FERMENTASI DENGAN SUPLEMENTASI ASAM AMINO LISIN, METIONIN, TRIPTOPAN SELAMA PRODUKSI TERHADAP PERFORMANS DAN KUALITAS INTERNAL SERTA KADAR KOLESTEROL TELUR AYAM RAS

Yosi Fenita dan Desia Kaharuddin
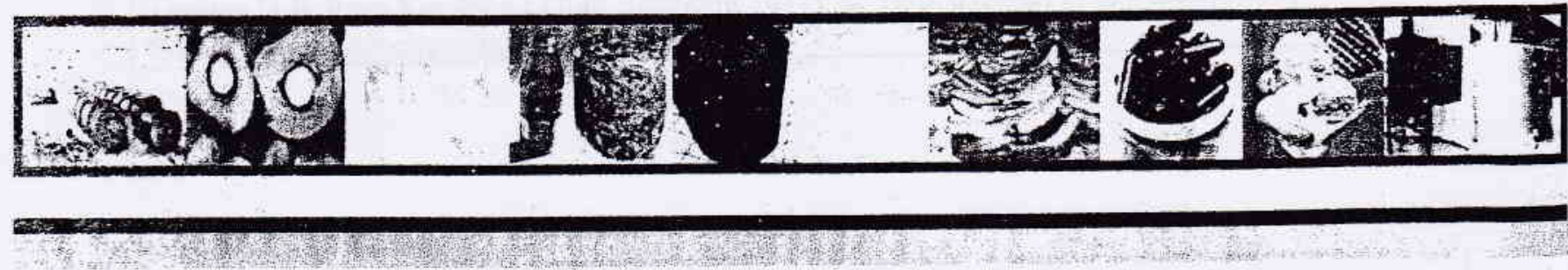


\section{KATA PENGANTAR}

Alhamdulillah, berkat dan rahmatNYA Penerbitan Jurnal Agroindustri nomor kedua dapat diselesaikan. Jurnal Agroindustri merupakan upaya meningkatkan media komunikasi ilmiah tentang Agroindustri dan Teknologi Pertanian, berisikan karya ilmiah berupa hasil penelitian, telaah pustaka serta pemikiran, bidang ilmu Teknologi Pertanian. Jurnal Agroindustri diharapkan memberi manfaat bagi para pengajar di Perguruan Tinggi, peneliti dan profesi untuk mempublikasikan karya ilmiahnya serta menjadi rujukan bagi pengguna.

Pada penerbitan ini adalah edisi no dua pada volume 1, topik karya ilmiah yang disajikan sudah bervariasi dari edisi no 1 . Pada edisi ini, terdapat dúa penulis yang bukan berasal dari Jurusan Teknologi Pertanian Universitas Bengkulu. Diharap kedepan akan lebih banyak karya ilmiah dari Peneliti Universitas lain untuk memperkaya khasanah keilmuan. Sebagai upaya untuk dapat memberikan manfaat yang luas bagi komunitas ilmiah pada bidang Ilmu Teknologi Pertanian, jumal ini akan kami distribusikan pada masyarakat ilmiah secara nasional. Selain itu, kami berharap peran serta, masukan dan partisipasi serta kritik dan saran yang membangun dari semua fihak.

Pada kesempatan ini, tim editor mengucapkan banyak terima kasih kepada Rektor Universitas Bengkulu dan Dekan Fakultas Pertanian Universitas Bengkal atas semua bantuan baik materil maupun spirit serta fasilitas atas penerbitan Jurnal Agroindustri Edisi perdana ini. Terima kasih juga disampaikan pada penulis atas kepercayaan mempublikasikan karya ilmiahnya. Serta ucapan terima kasih pada pembaca, semoga bermanfaat bagi semua

Bengkulu, 30 November 2011

Tim Editor

"JURNAL AGROINDUSTRI"

Media Komunikasi Ilmiah Tentang Agroindusiri dan Teknologi Pertanian

PENERBIT:

Jurusan Teknologi Pertanian, Fakultas Pertanian Universitas Bengkulu

KETUA REDAKSI :

Dr. Ir. Kurnia Harlina Dewi, MSi

DEWAN REDAKSI :

Prof. Dr. Yuwana, MSc

Dra. Devi Silsia, MSi;

Ir. Hasanuddin, MSc;

Evanila Silvia, STP. MSi;

Drs. Syafnil, MSi;

Yessy Rosalina, STP. MSi;

\section{ALAMAT REDAKSI:}

Jurusan Teknologi Pertanian, Fakultas Pertanian Universitas Bengkulu, Gedung U J. Raya Kandang Limun Bengkulu 38371 A, Teip. 0736-211770 Pesawat 214, E-mail : teknologipertanianunib@yahoo.co.id 


\title{
KAJIAN PEGGUNAAN BERBAGAI JENIS BIOBRIKET SEBAGAI ALTERNATIF PENGGANTI MINYAK TANAH UNTUK RUMAH TANGGA
}

\author{
Budiyanto, Pandu Imam dan Sari Puspita Ningsih \\ Teknologi Industri Pertanian Fakultas Pertanian \\ Universitas Bengkulu
}

\begin{abstract}
Biobriquet defined as fuel and solid which came from organic rested material. The formation of biomass into biobriquet intended to facilitate its utilizing. The use of biobriquet as alternative energy can replace the use of kerosene for burning needs in the household. This research is aimed to determine the best type of biobriquet based on the quality of burning performance produced by kerosene control and determine life time of biobriquet that have been packaged on plastic and paper bags that saved in temperature room. This research was conducted in the Laboratory of Agricultural Technology, Faculty of Agriculture, University of Bengkulu and PT Sucofindo Bengkulu. It examined four types of biobriquet which are palm shell charcoal biobriquet (A), Empty fruit bunch (EFB) charcoal + coal biobriquet (B), EFB charcoal biobriquet (C) and non-choarcoling oil palm shells biobriquet (D). Observed variables are the calorific value, moisture content, ash content, levels of substance to fly, lighting time, burning time, Water Boiling Test (WBT), Control Cooking Test (CCT), intensity of smoke, and water content changes in packaging of biobriquet. The results showed that non-choarcoling palm oil shells biobriquet (D) is the best biobriquet based on performance quality. If it compared with kerosene, non-choarcoling palm oil shells biobriquet (D) is better than kerosene, while in other biobriquets, kerosene is still the best one. Based on other biobriquet tests (water content, calorific value, ash content, levels of substance to fly, lighting time, burning time and fuel consumption biobriquet), the best biobriquet that replaced kerosene is TKKS charcoal biobriquet $(\mathrm{C})$, however, for the variables which compared with kerosene (burning time and fuel consumption), kerosene is still the best one. Biobriquet that packaged by using paper bags for 6 weeks the rising of water levels are relatively low compared with the plastic bags.
\end{abstract}

Keyword : biobriquet, empty fruit bunch, palm shell, packaged.

\section{PENDAHULUAN}

Indonesia memiliki potensi besar untuk memanfaatkan produk samping kelapa sawit sebagai sumber energi terbarukan. Kelapa sawit Indonesia merupakan salah satu komoditi yang mengalami pertumbuhan sangat pesat. Pengembangan produk samping sawit sebagai sumber energi alternatif memiliki beberapa kelebihan. Pertama, sumber energi tersebut merupakan sumber energi yang bersifat renewable sehingga bisa menjamin kesinambungan produksi. Kedua, Indonesia merupakan produsen utama minyak sawit sehingga ketersediaan bahan baku akan terjamin dan industri ini berbasis produksi dalam negeri. Ketiga, pengembangan alternatif tersebut merupakan proses produksi yang ramah lingkungan. Keempat, upaya tersebut juga merupakan salah satu bentuk optimasi pemanfaatan sumberdaya untuk meningkatkan nilai tambah. Diversifikasi yang dapat diupayakan adalah dengan mengoptimalkan potensi energi terbarukan (renewable), sehingga diperoleh bahan bakar yang murah dan mudah untuk didapatkan. (Mahajoeno, 2005). 
Mengingat pentingnya bahan bakar pengganti minyak tanah bagi rumah tangga kalangan menengah kebawah dan untuk meminimalkan kekurangan penggunaan briket batubara maka sangat diperlukan suatu penelitian untuk mengetahui jenis briket dengan nilai kalor dan lama nyala api yang cocok digunakan pada rumah tangga, dengan asap yang sedikit, waktu penyalaan yang cepat, dan proses pemasakan yang relatif cepat. Briket adalah bahan bakar padat yang dapat digunakan sebagai bahan bakar alternatif pengganti minyak tanah. Jenis - jenis briket berdasarkan bahan baku penyusunnya terdiri dari briket batubara, briket bio-batubara dan biobriket. Biobriket adalah bahan bakar padat yang terbuat dari bahan baku biomassa dengan campuran sedikit perekat (Anonim, 2006 dalam Wulan Sari, 2007). Bahan perekat yang sering digunakan dalam pembuatan briket adalah pati dengan konsentrasi tertentu. (Anonim,2004)

Biomassa dari produk samping sawit yang dapat dimanfaatkan sebagai sumber energi terbarukan adalah Tandan Kosong Kelapa Sawit (TKKS) dan cangkang sawit. Pengolahan tandan buah segar (TBS) menjadi Crude Palm Oil (CPO) dapat dihasilkan $15 \%$ TKKS dan $16 \%$ cangkang sawit. Limbah padat hasil pengolahan CPO ini sangat potensial untuk dijadikan biobriket sebagai energi alternarif apabila dilihat dari keberadaan TKKS dan cangkang sawit tersebut. Pembuatan biobriket dari cangkang sawit dan TKKS yang dilakukan bisa melalui pengarangan (bahan yang akan dibuat biobriket lebih dahulu diarangkan melalui pembakaran atau pirolisis) maupun tanpa pengarangan. (Mahajoeno, 2005). Potensi energi panas masing-masing produk samping kelapa sawit tersebut cukup besar, yaitu $20.093 \mathrm{Kj} / \mathrm{Kg}$ untuk cangkang kelapa sawit dan $18.798 \mathrm{Kj} / \mathrm{Kg}$ untuk TKKS (Didiek H. Goenadi, 2005).
Menurut Wulan Sari (2007), penambahan $19 \%$ cangkang sawit dalam $76 \%$ batubara dapat menghasilkan briket batubara yang mudah dinyalakan, asap dan gas emisi yang lebih sedikit serta menghasilkan panas dengan suhu tinggi. Perhitungan kalor (energi panas) juga dilakukan dalam penelitian ini.

Penelitian-penelitian mengenai biobriket cangkang kelapa sawit dan TKKS telah dilakukan dalam usaha menjadikannya sebagai bahan bakar rumah tangga, seperti pembuatan biobriket dari TTKS dengan pengarangan oleh Lusia (2008), pembuatan biobriket dari cangkang sawit dan batubara dengan pengarangan oleh Sari (2007) dan pembuatan biobriket dari cangkang sawit tanpa pengarangan oleh Yusri (2008). Namun penelitian-penelitian tersebut baru mengkaji karakeristik salah satu jenis biobriket saja melalui beberapa kombinasi perlakuan. Penelitian tersebut hanya mencari kombinasi perlakuan terbaik yang diteliti dan belum sampai pada pengemasan yang semi komersil. Penelitian mengenai beberapa jenis biobriket secara bersamaan untuk mencari jenis biobriket yang terbaik dengan pengemasannya belum dilakukan.

Berdasarkan beberapa masalah yang telah diuraikan diatas, maka perlu dilakukan penelitian terhadap beberapa jenis biobriket sehingga diperoleh hasil biobriket yang terbaik untuk dikembangkan sebagai pengganti bahan bakar rumah tangga.

Tujuan penelitian ini adalah : (1) Menentukan jenis biobriket yang terbaik berdasarkan kualitas kinerja pembakaran yang dihasilkan. (2) Menentukan daya simpan biobriket yang telah dikemas dan disimpan pada suhu kamar. 


\section{METODOLOGI PENELITIAN}

Bahan dan alat yang digunakan pada penelitian ini adalah tandan kosong kelapa sawit, cangkang kelapa sawit, minyak tanah, tepung tapioka, air, beras, batu bara, kertas semen, karung plastik, korek api, kompor briket, parang, alat penggerus, baskom, drum pengarangan, timbangan manual, ember, alat pencetak briket, thermometer, panci, neraca analitik, nampan, sendok, oven, gunting, bomb calorimeter, ayakan, ATK. Penelitian ini dilaksanakan pada bulan Mei - Agustus 2009 dilaboratorium Teknologi Pertanian Fakultas Pertanian Universitas Bengkulu dan Laboratorium PT Sucofindo Bengkulu.

Variabel yang diamati dalam penelitian ini adalah kadar air, nilai kalor, kadar abu, kadar zat terbang, waktu penyalaan, waktu pembakaran, waktu untuk memasak air, waktu untuk memasak nasi,konsumsi biobriket pada WBT dan CCT, kepekatan asap yang timbul dan Perubahan kadar air pada biobriket setelah dikemas selama enam minggu.

\section{Analisa Data}

Data yang diperoleh dari hasil pengujian Kadar air, nilai kalor, kadar abu, kadar zat terbang, waktu penyalaan, waktu pembakaran, waktu untuk memasak air, waktu untuk memasak nasi, konsumsi biobriket pada WBT dan CCT disajikan dalam bentuk grafik dan dilakukan analisa sidik ragam (uji F) pada taraf $5 \%$, dan apabila terdapat perbedaan nyata untuk setiap perlakuan yang ada maka dilakukan uji lanjut DMRT (Duncant Multiple Range Test) pada taraf signifikan $5 \%$ (Gomez dan Gomez, 1995). Sedangkan untuk kepekatan asap uji lanjutnya menggunakan uji Least Significant Difference (LSD) (Kartika et al.,1988).

\section{HASIL DAN PEMBAHASAN}

\section{Karakteristik Empat Jenis Biobriket}

Bioriket dicetak dengan tinggi $7 \mathrm{~cm}$, diameter $4,5 \mathrm{~cm}$, diameter lubang atas $1,2 \mathrm{~cm}$, diameter lubang bawah $1,5 \mathrm{~cm}$. Ketiga dimensi ini digunakan untuk tiga jenis biobriket yaitu arang cangkang sawit, campuran arang TKKS dan batubara serta arang TKKS (biobriket yang diarangkan). Sedangkan biobriket cangkang sawit tanpa pengarangan tidak menggunakan lubang ditengahnya.

\section{Hasil Uji Kadar Air}

Setelah biobriket dicetak kemudian dijemur dengan menggunakan sinar matahari selama 4 hari. Penjemuran dalam satu hari dilakukan selama 6 jam (9.00 WIB - 16.00 WIB), tujuan dari penjemuran ini untuk mengurangi kadar air dari biobriket tersebut hingga mencapai kadar air pada standar biobriket yang berlaku. Kadar air biobriket dapat dilihat pada gambar 1 .

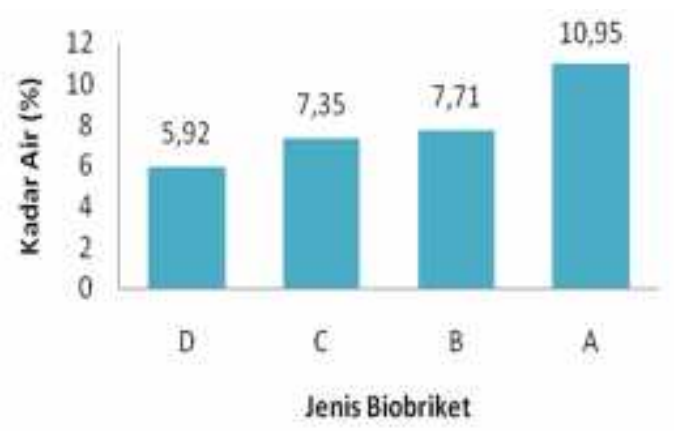

Gambar 1. Kadar air biobriket

Keterangan :

A : Biobriket arang cangkang sawit

B : Biobriket arang TKKS + batubara

C : Biobriket arang TKKS

D : Biobriket cangkang sawit tanpa pengarangan

Apabila kadar air biobriket arang TKKS dan arang TKKS + batubara 
dibandingkan dengan standar kadar air biobriket arang cangkang kelapa sawit, maka kadar air biobriket arang TKKS dan campuran arang TKKS dan batubara $(7,71 \%)$ berada diatas standar kadar air biobriket arang cangkang sawit $(8,47 \%)$. Sedangkan kadar air biobriket arang cangkang kelapa sawit (10,95\%) masih berada dibawah standar $(8,47 \%)$. Hal yang berpengaruh pada tingginya kadar air adalah waktu penjemuran dan pembalikan biobriket saat penjemuran. Hasil analisa keragaman menunjukkan $\mathrm{F}$ hitung > daripada $\mathrm{F}$ tabel, sehingga dilakukan uji lanjut DMRT yang menghasilkan kadar air biobriket A dan biobriket $\mathrm{D}$ berbeda nyata dengan semua jenis biobriket. Sedangkan biobriket B dan biobriket $\mathrm{C}$ saling tidak berbeda nyata tetapi berbeda nyata dengan jenis biobriket lainnya.

\section{Nilai Kalor}

Keempat jenis biobriket menghasilkan nilai kalor diatas $4.500 \mathrm{kkal} / \mathrm{kg}$. Nilai kalor yang masing-masing jenis biobriket dapat dilihat pada gambar 2 .

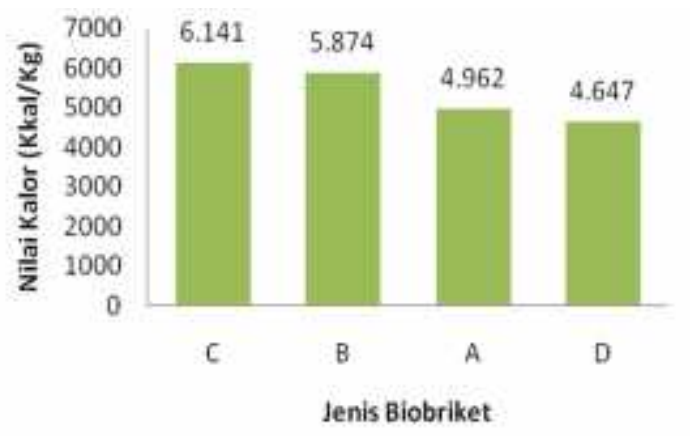

Gambar 2. Nilai Kalor Biobriket

Bila dibandingkan dengan standard kualitas arang kayu nilai kalor yang diperoleh ketiga jenis biobriket arang telah memenuhi stándar SNI 01-6235-2000 yaitu minimal $5000 \mathrm{kkal} / \mathrm{kg}$. Biobriket arang cangkang sawit (A) dan biobriket cangkang sawit tanpa pengarangan masih berada di bawah standard.
Menurut Sukandarumidi (2006), nilai kalor biobriket dipengaruhi oleh kadar air, kadar abu, kadar volatile matter dan fixed karbonnya. Semakin tinggi kadar air, kadar abu dan kadar volatile matter serta semakin rendahnya fixed karbon maka nilai kalor semakin rendah (pada biobriket yang melalui proses pengarangan). Hasil analisa keragaman menunjukkan bahwa $\mathrm{F}$ hitung > daripada $F$ tabel sehingga dilakukan uji lanjut DMRT yang menghasilkan nilai kalor seluruh jenis biobriket berbeda nyata.

\section{Uji Kadar Abu}

Jika dibandingkan dengan standar karakteristik (kadar abu) ketiga biobriket berada diatas standard kadar abu $(9,65 \%)$. Biobriket arang cangkang sawit memiliki kadar abu dibawah standard kadar abu pada biobriket yaitu $11,73 \%$.

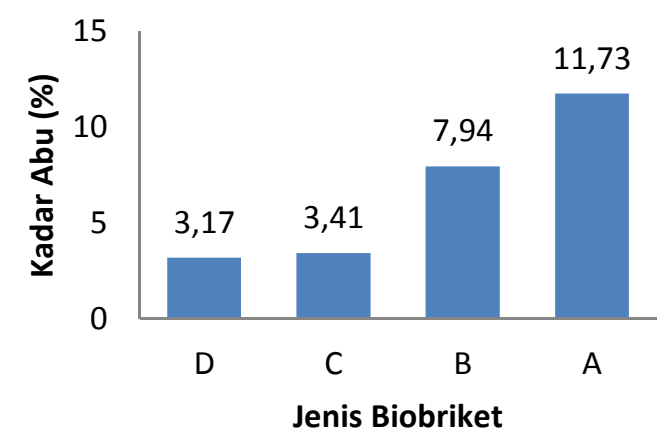

Gambar 3. Kadar Abu Biobriket

Biobriket yang terbaik berdasakan kadar abunya adalah cangkang sawit tanpa pengarangan dan arang TKKS, biobriket arang TKKS+batubara dan terakhir arang cangkang sawit tanpa pengarangan. Tingginya kadar abu ini dipengaruhi oleh tingginya kadar air yang dihasilkan oleh biobriket (Sukandarumidi, 2006). Hasil analisa keragaman menunjukkan bahwa $\mathrm{F}$ hitung > daripada $F$ tabel sehingga dilakukan uji lanjut DMRT yang menghasilkan kadar abu jenis biobriket A dan B berbeda nyata dengan semua jenis 
biobriket. Sedangkan biobriket C dan biobriket $\mathrm{D}$ saling tidak berbeda nyata tetapi berbeda nyata dengan biobriket lainnya.

\section{Kadar Zat terbang}

Kadar zat terbang semua jenis biobriket berada diatas standar $(21,10 \%)$. Biobriket terbaik berdasarkan zat terbangnya adalah biobriket arang cangkang sawit, setelah ini arang TKKS + batubara dan arang TKKS dan terakhir cangkang sawit tanpa pengarangan. Tingginya kadar zat terbang akan berpengaruh pada waktu penyalaan biobriket (Sari, 2007).

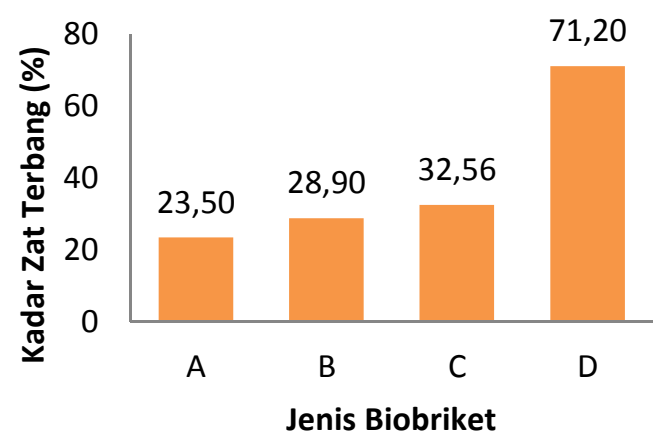

Gambar 4. Kadar Zat Terbang Biobriket

Hasil analisa keragaman menunjukkan bahwa $\mathrm{F}$ hitung > daripada $\mathrm{F}$ tabel sehingga dilakukan uji lanjut DMRT yang menghasilkan kadar zat terbang biobriket A dan D berbeda nyata dengan semua jenis biobriket. Sedangkan biobriket B dan biobriket $\mathrm{C}$ saling tidak berbeda nyata tetapi berbeda nyata dengan biobriket lainnya.

\section{Waktu Penyalaan}

Pada penelitian ini waktu yang dibutuhkan untuk menyalakan biobriket berbeda-beda, waktu penyalaan biobriket antara 5,93 - 10,51 menit.

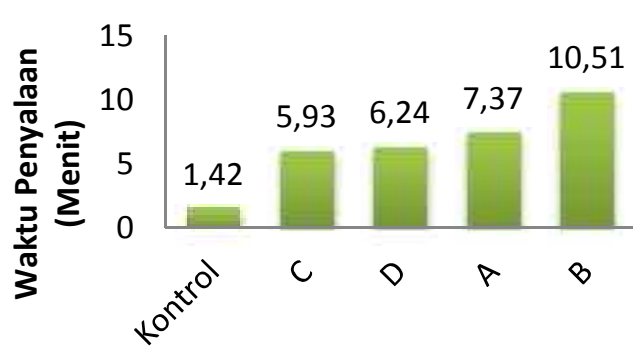

Jenis Biobriket

Gambar 5. Waktu Penyalaan (menit)

Menurut Sukandarrumidi (2006), parameter kualitas batubara yang sangat mempengaruhi waktu yang dibutuhkan untuk menyalakan briket adalah kadar air, kadar abu dan kadar volatile matternya. Jika kadar air dan kadar abu tinggi dan kadar volatile matternya rendah membuat pembakaran briket sulit sehingga waktu yang dibutuhkan untuk menyalakan briket banyak.

Selain kesempurnaan pembakaran waktu yang dibutuhkan untuk menyalakan briket sangat dipengaruhi dari kualitas bahan baku yang digunakan, bahan perekat dan bahan tambahan. Disamping itu jenis dan jumlah penyulut awal yang digunakan juga mempengaruhi banyaknya waktu yang dibutuhkan untuk menyalakan briket. Semakin banyak jumlah penyulut yang digunakan maka semakin cepat briket menyala.

Hasil analisa keragaman menunjukkan bahwa $\mathrm{F}$ hitung > daripada $\mathrm{F}$ tabel sehingga dilakukan uji lanjut DMRT yang menghasilkan bahwa waktu penyalaan seluruh jenis biobriket saling berbeda nyata.

\section{Waktu Pembakaran}

Waktu Pembakaran terdiri dari waktu nyala dan waktu bara. Waktu nyala dihitung sebagai waktu pembakaran dalam bentuk nyala. Sedangkan api yang hidup pada briket dari nyala mulai padam hingga habis menjadi abu, dihitung sebagai waktu 
pembakaran dalam bentuk bara. Sehingga, waktu total pembakaran adalah total waktu dalam bentuk nyala dan dalam bentuk bara (Departemen Energi dan Sumber Daya Mineral, 2006).

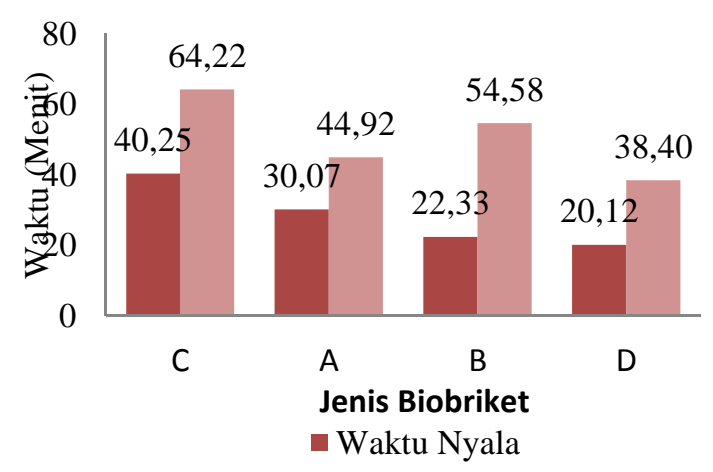

Gambar 6. Waktu Pembakaran

Biobriket arang TKKS memiliki waktu nyala dan waktu bara paling lama. Salah satu yang menyebabkan hal ini terjadi adalah nilai kalori yang dimiliki oleh biobriket (Sukandarumidi, 2006). Selain itu massa arang TKKS saat waktu pembakaran adalah paling besar. Setelah arang TKKS, waktu nyala paling lama terdapat pada arang cangkang sawit, namun waktu bara terlama terdapat pada arang TKKS + batubara. Hal ini terjadi karena batubara bersifat susah terbakar.

Hasil analisa keragaman menunjukkan bahwa $\mathrm{F}$ hitung > daripada $\mathrm{F}$ tabel sehingga dilakukan uji lanjut DMRT yang menghasilkan waktu nyala dan waktu bara seluruh jenis biobriket saling berbeda nyata.

\section{Hasil Pengamatan Water Boiling Test (WBT)}

Pada pengamatan WBT parameter yang harus diukur adalah waktu yang dibutuhkan untuk memasak air dan konsumsi bahan bakar biobriket.

\section{Waktu Memasak Air}

Biobriket campuran arang TKKS dan batubara memiliki waktu yang paling lama untuk mendidihkan air. Biobriket ini juga memiliki waktu paling lama dalam penyalaannya. Hal ini menunjukkan bahwa pembakaran biobriket campuran arang TKKS dan batubara sangat sulit menghasilkan api pada proses pembakaran. Nyala api yang dihasilkan oleh biobriket campuran arang TKKS dan batubara paling kecil bila dibandingkan dengan ketiga jenis biobriket lainnya.

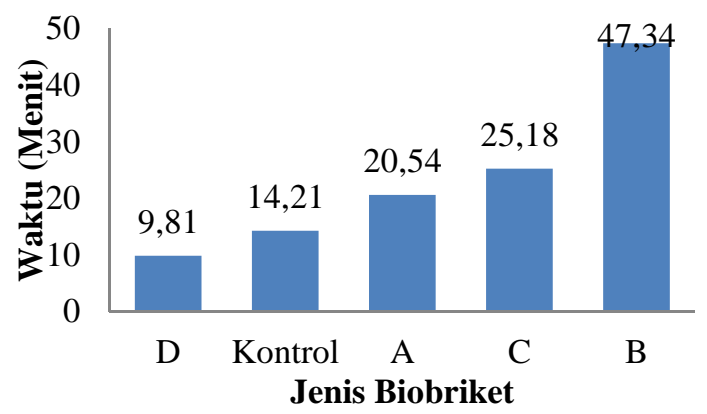

Gambar 7. Waktu Memasak Air

Hasil analisa keragaman waktu memasak air menunjukkan bahwa $\mathrm{F}$ hit $>\mathrm{F}$ tabel. Sehingga dilakukan uji lanjut DMRT yang menunjukkan bahwa seluruh waktu yang diperlukan untuk mendidihkan air semua jenis biobriket berbeda nyata.

\section{Konsumsi Biobriket}

Konsumsi biobriket paling tinggi terdapat pada biobriket D (cangkang sawit tanpa pengarangan) yaitu 329,47. Sedangkan penggunaan biobriket paling sedikit terdapat pada biobriket C (arang TKKS) yaitu 188,00 gram.

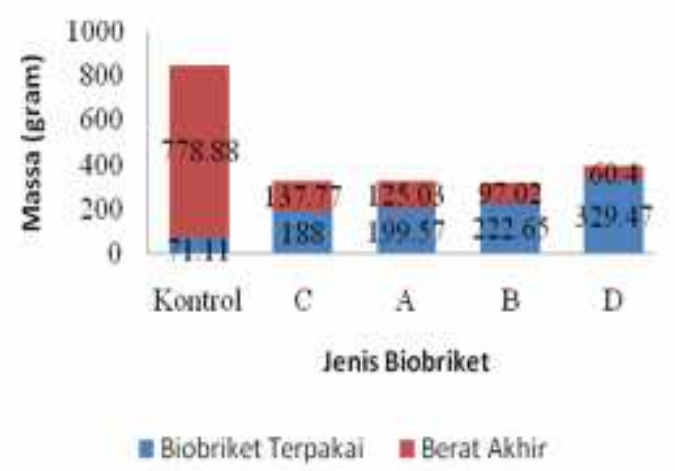

Gambar 8. Konsumsi Biobriket 
Hasil analisa keragaman konsumsi biobriket menunjukkan bahwa $\mathrm{F}$ hitung > daripada $F$ tabel sehingga dilakukan uji lanjut DMRT yang menunjukkan konsumsi seluruh jenis biobriket saling berbeda nyata.

\section{Hasil Pengamatan Control Cooking Test (CCT)}

Pada pengamatan CCT parameter yang harus diamati adalah waktu yang digunakan untuk memasak nasi dan konsumsi bahan bakar biobriket.

\section{Waktu Memasak Nasi}

Dari penelitian yang telah dilakukan, waktu memasak nasi yang paling cepat terdapat pada cangkang sawit tanpa pengarangan yaitu 29,48 menit. Sedangkan waktu yang paling lama untuk memasak nasi terdapat pada campuran arang TKKS + batubara yaitu 39,37 menit.

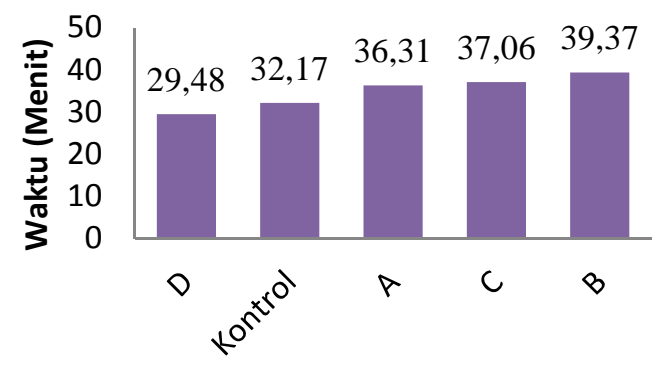

Jenis Biobriket

Gambar 9. Waktu Memasak Nasi

Hasil analisa keragaman waktu yang digunakan untuk memasak nasi menunjukkan bahwa $\mathrm{F}$ hitung $>$ daripada $\mathrm{F}$ tabel sehingga dilakukan uji lanjut DMRT yang menunjukkan waktu yang digunakan untuk memasak nasi dari seluruh jenis biobriket saling berbeda nyata.

Sifat batubara yang sulit terbakar, menyebabkan batubara memerlukan waktu yang paling lama untuk memasak nasi. Bila keempat biobriket ini dibandingkan dengan kontrol minyak tanah, waktu yang diperlukan untuk memasak nasi tidak terlampau berbeda.

\section{Konsumsi Bahan Bakar Biobriket}

Konsumsi bahan bakar biobriket tertinggi terdapat pada biobriket D (cangkang sawit tanpa pengarangan) yaitu 281,23 gram. Sedangkan konsumsi biobriket terendah terdapat pada biobriket C (arang TKKS) yaitu 200,60 gram.

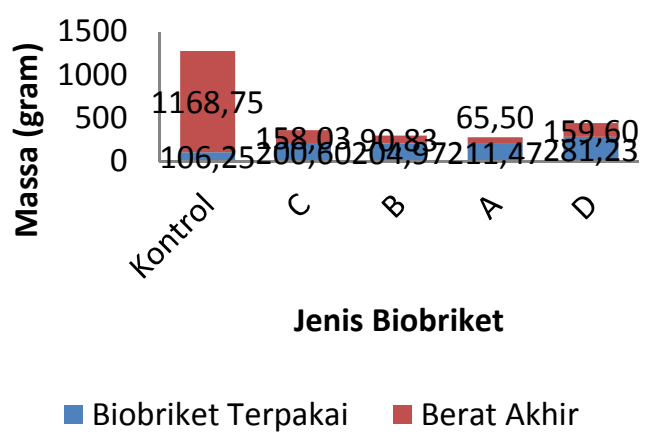

Gambar 10. Konsumsi Bahan Bakar

Hasil analisa keragaman konsumsi bahan bakar biobriket menunjukkan bahwa $\mathrm{F}$ hitung $>$ daripada $\mathrm{F}$ tabel sehingga dilakukan uji lanjut DMRT yang menunjukkan konsumsi biobriket untuk memasak nasi dari seluruh jenis biobriket saling berbeda nyata.

Hal yang mempengaruhi dalam banyaknya biobriket yang digunakan adalah nilai kalor yang dimiliki oleh biobriket tersebut.

\section{Smoke Sensory Test (SST)}

Penilaian terhadap asap yang dihasilkan dari pembakaran briket dilakukan secara visual dari mulai briket dinyalakan sampai briket menyala bersih ditandai dengan api yang berwarna kuning kebiruan. Pembakaran briket dilakukan di dalam ruangan yang terdapat sirkulasi udara. Pembakaran briket dilakukan dengan cara menyalakan 5 buah biobriket untuk tiap jenisnya, salah satu dari kelima buah biobriket tersebut menjadi sebagai penyulut 
dengan memasukkan 1 buah biobriket kedalam minyak tanah selama 10 detik.

Menurut Departemen Energi dan Sumberdaya Mineral (2006), pembakaran dari atas dimaksudkan agar pembakaran briket terjadi sempurna, kesempurnaan pembakaran briket akan sangat berpengaruh pada asap yang dihasilkan.

Selain kesempurnaan pembakaran, asap yang dihasilkan dari pembakaran briket juga ditentukan oleh kualitas bahan baku (batubara), bahan perekat dan bahan tambahan yang digunakan serta kondisi dimana briket dinyalakan.

Menurut Sukandarrumidi (2006), parameter-parameter kualitas batubara yang akan sangat mempengaruhi adalah kadar air, kadar abu dan kadar zat terbang (Volatil Matter). Semakin tinggi kadar air, kadar abu dan kadar zat terbang, maka asap yang akan dihasilkan dari pembakaran banyak.

\section{Pengamatan Pengemasan Biobriket Selama 6 minggu}

Tabel. 1. Kenaikan Kadar Air Pengemasan Biobriket Pada Kertas Semen

\begin{tabular}{|c|c|c|c|}
\hline Jenis & Minggu & Minggu & Minggu \\
\hline Biobriket & 2 & 4 & 6 \\
\hline A & 0,3 & 0,52 & 0,21 \\
\hline B & 0,47 & 0,51 & 0,04 \\
\hline $\mathrm{C}$ & 0,24 & 0,73 & 0,14 \\
\hline D & 0,46 & 1,09 & 0,03 \\
\hline
\end{tabular}

Tabel 2. Kenaikan Kadar Air Pengemasan Biobriket Pada Karung Plastik

\begin{tabular}{|c|c|c|c|}
\hline Jenis & Minggu & Minggu & Minggu \\
\hline Biobriket & 2 & 4 & 6 \\
\hline A & 0,44 & 1,29 & 1,32 \\
\hline B & 0,55 & 0,76 & 0,98 \\
\hline $\mathrm{C}$ & 0,29 & 1,19 & 2,64 \\
\hline D & 0,18 & 1,58 & 2,45 \\
\hline
\end{tabular}

Apabila diperhatikan pada Tabel 1 dan 2 kenaikan kadar air biobriket lebih sedikit pada bahan pengemasan kertas semen dibandingkan pada karung plastik. Menurut Anonim (2008) Kelemahan bahan pengemas plastik adalah tidak tahan panas, tidak hermetis (plastik masih bisa ditembus udara melalui pori-pori plastik), dan mudah terjadi pengembunan uap air didalam kemasan ketika suhu turun. Menurut Erdansyah (2009).

Kertas semen merupakan jenis kertas yang memiliki serat lebih kuat dari pada kertas biasa. Selain lebih kuat, kertas semen juga memiliki ketebalan dan kelenturan yang cukup baik untuk membukus bendabenda yang berukuran kecil. Namun pada penelitian ini bahan pengemas yang digunakan belum mampu menahan naiknya kadar air pada biobriket yang telah dikemas. Hal ini dapat dipengaruhi oleh kelembaban ruangan saat penyimpanan, perubahan tekanan sebagian uap air di udara berhubungan dengan perubahan suhu diruangan tersebut.

\section{KESIMPULAN DAN SARAN}

\section{Kesimpulan}

1. Urutan biobriket terbaik berdasarkan kinerja pembakaran (Water Boiling Test (WBT), Control Cooking Test $(C C T)$ dan Smoke Sensory Test (SST)) berturut-turut adalah biobriket cangkang sawit tanpa pengarangan (D), arang cangkang sawit (A), arang TKKS (C) dan arang TKKS + batubara (B). Biobriket cangkang sawit tanpa pengarangan lebih baik dibanding minyak tanah. Cangkang sawit tanpa pengarangan memilki kadar air paling rendah dan waktu penyalaan yang paling cepat dibandingkan ketiga biobriket lainnya.

2. Berdasarkan pengujian biobriket yang lain (kadar air, nilai kalor, kadar abu, kadar zat terbang, waktu penyalaan, waktu pembakaran dan konsumsi 
bahan bakar biobriket), urutan biobriket pengganti minyak tanah yang terbaik adalah biobriket arang TKKS (C), biobriket cangkang sawit tanpa pengarangan (D), biobriket arang cangkang sawit (A) dan biobriket arang TKKS + batubara. Namun demikian untuk variabel yang dibandingkan dengan minyak tanah (waktu pembakaran dan konsumsi bahan bakar), minyak tanah masih tetap yang terbaik.

3. Pengemasan biobriket menggunakan bahan pengemas kertas semen selama 6 minggu kenaikannya relatif rendah dibandingkan dengan pengemas karung plastik.

\section{Saran}

1. Saat dilakukan uji pembakaran empat jenis biobriket, panas pada kompor saat pengujian pertama akan mempengaruhi pengujian selanjutnya. Untuk itu saat uji pembakaran diperlukan jumlah kompor yang sesuai dengan jumlah biobriket yang akan diuji agar pengujian dilakukan bersamaan.

2. Saat dilakukan Control Cooking Test (CCT) khususnya untuk memasak yang memerlukan api kecil, kompor briket sulit dalam pengaturan apinya. Untuk itu perlu dilakukan uji lanjut tentang desain kompor untuk memasak yang memerlukan api kecil.

3. Penyimpanan biobriket sebaiknya menggunakan kertas semen agar kenaikan kadar air tidak terlalu tinggi dan ruang yang digunakan untuk menyimpan biobriket seharusnya terkontrol. Apabila akan dilakukan pengiriman biobriket, sebaiknya dilakukan pengemasan sekunder dengan menggunakan kardus.

\section{DAFTAR PUSTAKA}

Anonim. 2004. Peluang Pengembangan Briket Batubara. http://www.dpmb.esdm.go.id/module s/_news/news_detail,php?artikel. 7 Februari 2009.

Anonim. 2008. Summary Evaluation Report of Fuel-Efficient Stoves in Darfur IDP Camps, Academy for EducationalDevelopment,www, usaid ,gov/our_work/economic_growth_an d_trade/energy/Publicatios/EG AT0020,PDF .1 Februari 2009.

Anonim. 2008 ${ }^{\mathrm{b}}$ Kenaikan Harga BBM. http://pebisnis-sejati.blogspot.com/ (bisnis KS). Mei 2008.

Anonim. 2008.

http://usahabriket.blogspot.com/. 19 Agustus 2009

Didiek H, Goenadi , Wayan R, Susila dan Isroi. 2005. Pemanfaatan Produk Samping Kelapa Sawit Sebagai Sumber Energi Alternatif Terbarukan, http://isroi,wordpress,com/2008/03/1 2/-produk-samping-kelapa-sawitsebagai-sumber-energi-alternatifterbarukan/.

17 Januari 2009.

Erdansyah, F. 2009. Pengemasan Bahan Pengan.

http://www.smallcrab.com/kesehatan /25-healthy/503-pengemasan-bahanpangan. 19 Agustus 2009.

Gomez. K.A dan Gomez A.A. 1984. Statistical Procedures For Agricultural Research, 2nd Edition. John Wiley dan Sons, Inc. Diterjemahkan oleh Sjamsuddin, E 
dan Baharsjah, J. 1995. Prosedur Statistik untuk Penelitian Pertanian. UI-Press. Jakarta .

Kartika, B., A.D. Guritno, D. Purwadi, dan D. Ismoyowati. 1988. Petunjuk Evaluasi Produk Industri Hasil Pertanian. Universitas Gajah Mada. Yogyakarta

Lusia. 2008. Pembuatan Briket Dengan Komposisi Limbah Cair CPO (Crude Palm Oil) dan Arang Tandan Kosong Kelapa Sawit, Universitas Bengkulu, Bengkulu, (Skripsi Tidak dipublikasikan)

Mahajoeno, E. 2005. Energi Alternatif Pengganti BBM : Potensi Limbah Biomassa sawit Sebagai Sumber Energi Terbarukan. http://www,ipard,com/art_perkebuna n/apr11-05_isr+edw,asp, Artikel. 7 februari 2009

Sari, W. 2007. Kajian Penambahan Arang Cangkang Sawit Dalam Pembuatan Briket Batu Bara Untuk Bahan Bakar Rumah Tangga, Universitas Bengkulu. Bengkulu. Skripsi Fakultas Pertanian (Tidak dipublikasikan).

SNI 2000. Brket Arang Kayu. SNI 01-62352000. Departemen Teknik Pertanian, Jakarta.

Sukandarrumidi, S. 2006. Batubara dan Pemanfaatannya. Gajah Mada Universitas Press. Yogyakarta.

Yusri. 2008. Kajian Pemanfaatan Limbah Padat (Cangkang) Pabrik Pengolahan Kelapa Sawit (PPKS) Menjadi briket Murni (Tanpa Pengarangan) Sebagai
Energi Alternatif. Skripsi (tidak dipublikasikan) 